\title{
AZAS-AZAS KEBIJAKAN SISTEM PENYELENGGARAAN KETENAGAKERJAAN DI KABUPATEN PASURUAN
}

\section{Hambali}

hambali@yudharta.ac.id

Fakultas Ilmu Administrasi, Universitas Brawijaya

\begin{abstract}
Government efforts in overcoming the global economic crisis are carried out jointly with the community, especially business people, one of the main reasons for stabilizing the economy and maintaining monetary balance and avoiding the bankruptcy of most companies that have an impact on the majority of workers and ends in termination of relations work. So the role of the actors in implementing local regulations is expected to be overcome, and can realize the capability that exists so that they can run local regulations and can improve their respective roles which ultimately can create a balance between the government, companies and workers who are disadvantaged but with the high school to get good welfare company workers and the government so that they can improve performance with a work ethic, then show human resources that can encourage economic growth and development and realize advanced regions, independent work competitiveness and no more problems for implementing actors Implementation of the Perda. This study was designed with a qualitative research method that uses a case study approach to determine the role of actors in implementing Regional Regulation No. 22 of 2012 concerning the Employment Management System (Study of Industrial Relations in Pasuruan Regency. The data analysis uses interactive model data analysis developed by Miles, Huberman and Saldana, while data collection was conducted through literature studies, field observations, and indept interviews, all data were simulated in depth, comprehensively, and corrected each other in a Focus Group Discussion (FGD).
\end{abstract}

Keywords: Local Regulation, Employment, Implementation of Public Policy. 
288 \} A Azas-Azas Kebijakan Sistem Penyelenggaraan Ketenagakerjaan

\section{PENDAHULUAN}

Produk hukum ketenagakerjaan tidak semata mementingkan pelaku usaha, melainkan memperhatikan dan memberi perlindungan kepada pekerja yang secara sosial mempunyai kedudukan sangat lemah, jika dibandingkan dengan posisi pengusaha yang cukup mapan. Hukum memberi manfaat terhadap prinsip perbedaan sosial serta tingkat ekonomi bagi pekerja yang kurang beruntung, antara lain seperti tingkat kesejahteraan, standar pengupahan serta syarat kerja, sebagaimana diatur dalam peraturan perundang-undangan dan selaras dengan makna keadilan menurut ketentuan Pasal 27 ayat 2 Undang-Undang Dasar 1945, bahwa : "Tiap-tiap warga negara berhak atas pekerjaan dan penghidupan yang layak bagi kemanusiaan". Demikian pula ketentuan Pasal 28 D ayat (2) Undang-Undang Dasar 1945, bahwa: "Setiap orang berhak untuk bekerja serta mendapat imbalan dan perlakuan yang adil dan layak dalam hubungan kerja", produk hukum normatif pada tingkat implementasi memberikan kontribusi dalam bentuk pengawasan melalui aparat penegak hukum dan melaksanakan penindakan terhadap pihak-pihak yang tidak mematuhi ketentuan hukum. Sedangkan menurut Peraturan Bupati Pasuruan Kabupaten Pasuruan Nomor 16 Tahun 2013 Tentang Petunjuk Teknis Pelaksanaan Program Pembangunan Partisipatif Kabupaten Pasuruan, desa didefinisikan sebagai berikut "Desa adalah kesatuan masyarakat hukum yang memiliki kewenangan untuk mengatur dan mengurus kepentingan masyarakat setempat yang diakui dalam sistem pemerintahan nasional dan berada di daerah Kabupaten".

Prisma Pembangunan yang berbasis strategi orientasi ekspor menuntut dipersiapkannya angkatan kerja industri yang disiplin serta upah dan kondisi kerja yang buruk, karena hanya dengan cara itu produk-produk kita bisa bersaing di arena pasar internasional. Untuk memudahkan aplikasi strategi itu maka pemerintah mengeluarkan berbagai kebijakan yang kurang menguntungkan buruh, tetapi sebaliknya memberikan ruang gerak yang lebih leluasa dan jaminan stabilitas kepada para pengusaha untuk melakukan akumulasi capital.

Ada beberapa kebijakan yang secara langsung melemahkan posisi tawar buruh dan juga mempersempit ruang gerak buruh diantaranya: Pertama, upaya-upaya yang secara sistematis melemahkan posisi tawar buruh dengan memandulkan serikat pekerja. Kedua Tindakan represif dan intimidatif dari aparat keamanan terhadap kaum buruh yang dianggap 
potensial mengancam stabilitas nasional. Ketiga Prosedur penyelesaian konflik perburuhan yang menutup ruang gerak pihak lain untuk ikut secara formal menangani masalah perburuhan. Birokrasi penyelesaian juga terlalu panjang. Dalam kondisi seperti ini hampir selalu buruh kalah sebelum vonis dijatuhkan. Secara terperinci, penelitian ini memiliki tujuan khusus, yakni: mendeskripsikan, menganalisis, dan menginterpretasikan tentang peran aktor dalam Implementasi Peraturan Daerah Nomor 22 tahun 2012 Tentang Sistem ketenagaan di Kabupaten Pasuruan. Permasalahan permasalahan yang ada dalam ketengakerjaan di Kabupaten Pasuruan.

\section{KAJIAN PUSTAKA}

\section{Landasan State The Art}

Yasin mengatakan bahwasannya implementasi kebijakan pada prinsipnya adalah cara agar sebuah kebijakan dapat mencapai tujuannya. Tidak lebih dan tidak kurang. Untuk mengimplementasikan kebijakan publik, ada dua pilihan langkah yang ada, yaitu langsung mengimplementasikan dalam bentuk program atau melalui formulasi kebijakan derivat atau turunan dari kebijakan publik tersebut. ${ }^{1}$

Pengertian implementasi kebijakan dan faktor-faktor yang mempengaruhi keberhasilan suatu implementasi Van Meter dan Van Horn juga mengemukakan beberapa hal yang dapat mempengaruhi keberhasilan suatu implementasi, yaitu: (1) Ukuran dan tujuan kebijakan, (2) Sumber-sumber kebijakan, (3) Ciri-ciri atau sifat Badan/Instansi pelaksana (4) Komunikasi antar organisasi terkait dengan kegiatan-kegiatan pelaksanaan, (5) Sikap para pelaksana, dan Lingkungan Ekonomi, Sosial dan Politik. ${ }^{2}$

\section{Konsep Peranan}

Peranan merupakan aspek yang dinamis dari kududukan (status). Apabila seseorang melaksanakan hak dan kewajibannya sesuai dengan kedudukannya, maka hal ini berarti menjalankan suatu peranan. Keduanya tidak dapat dipisah-pisahkan dan saling bertentangan satu dengan yang lain. Setiap orang mempunyai macammacam peranan yang berasal dari pola-pola pergaulan hidupnya. Hal

\footnotetext{
${ }^{1}$ Yasin, Moch. 2000. Dasar-dasar Demografi. Lembaga Demografi FEUI, Jakarta. 221.

${ }^{2}$ Mattew B. Miles, A. Michael Hubberman, and Johnny Saldana (2014). Qualitative Data Analysis: A Methods Sourcebook (3rd Edition) Arizona State University, CA: Sage Publications.
} 
290 \} A Azas-Azas Kebijakan Sistem Penyelenggaraan Ketenagakerjaan

tersebut sekaligus berarti bahwa peranan menentukan apa saja yang diperbuatnya bagi masyarakat kepadanya. Peranan lebih banyak menekankan pada fungsi, penyesuaian diri dan sebagai suatu proses. ${ }^{3}$ Jadi peranan menunjukkan keterlibatan diri atau keikutsertaan individu, kelompok yang melakukan suatu usaha untuk mencapai tujuan tertentu atas suatu tugas atau bukti yang sudah merupakan kewajiban dan harus dilakukan sesuai dengan kedudukannya. ${ }^{4}$

\section{METODE PENELITIAN}

\section{Teknik Pengumpulan Data dan Analisis Data}

Teknik pengumpulan data yang digunakan dalam penelitian ini adalah dengan menggunakan teknik:

a. Wawancara, dilakukan untuk mendapatkan data lapangan guna memperdalam pengetahuan tentang objek penelitian. Langkah ini dilakukan Peneliti untuk meminimalisir kesalahan dalam menginterpretasikan makna simbol-simbol atau kegiatan subjek penelitian yang berkaitan dengan masalah penelitian. Dalam hal ini pengumpulan data lebih lengkap, mendalam dan akurat sehingga membantu peneliti untuk menganalisis permasalahan penelitian secara lebih tajam mengenai fokus penelitian Kepatuhan Pegawai dalam Implementasi Kebijakan Kawasan Pelaksanaan Sistem Ketenagaan di Kabupaten Pasuruan dengan Informan penelitian, meliputi: Kepala Disnakertrans Kabupaten Pasuruan, Kepala Dinas Satuan Polisi Pamong Praja kabupaten Pasuruan sebagai penegak perda, para Pengusaha, para buruh dari berbagai Perusahaan di Kabupaten Pasuruan

b. Observasi yang dilakukan dalam penelitian ini merupakan observasi partisipan yakni peneliti mengamati secara langsung dan mencatat informasi yang berkaitan dengan objek yang akan diteliti secara sistematik yakni Implementasi Kebijakan Sistem Ketenagaan di Kabupaten Pasuruan, baik pada saat supervisi maupun perilaku merokok pegawai yang terjadi di Instansi Pemerintahan kabupaten Pasuruan yang berkaitan dengan fokus penelitian berupa kepatuhan

\footnotetext{
${ }^{3}$ Susanto Harris. 2012 Matinya Sang Buruh Penerbit Koekoesan Jl.KH.Ahmad Dahlan V.N0.10 Kukusan, Depok. 23.

4 Hakim, Lukman. 1999. Kajian Kebijakan Publik. makalah pada diklat SPAMEN angkatan V kelas E, Jakarta.
}

..::: Malia: Jurnal Ekonomi Islam, Volume 10 Nomor 2 Juni 2019 :::.. 
pegawai/buruh dan pengusaha dalam Implementasi Kebijakan Sistem Ketenagaan di Kabupaten Pasuruan

\section{Analisis Data}

Data dianalisis dengan menggunakan analisis data model interaktif yang dikembangkan oleh Miles, Huberman dan Saldana, yang terdiri dari alur kegiatan: kondensasi data (Data Condensation), menampilkan data (Data Display) dan penarikan kesimpulan/verifikasi (Conclusion Drawing/Verification). ${ }^{5}$

Kondensasi data diarahkan pada analisis yang mempertajam, menggolongkan, memfokuskan, membuang, dan mengorganisir data sehingga kesimpulan 'final' bisa ditarik atau diverifikasi sesuai dengan fokus penelitian yakni peran actor dalam implementasi Peraturan Daerah. Display data di desain untuk merakit informasi yang terorganisir ke dalam bentuk yang padat dan langsung dapat diakses sehingga analis dapat melihat apa yang sedang terjadi dan dapat menarik kesimpulan yang benar atau pun melangkah ketahap analisa berikutnya. Data-data yang disajikan tentang peran actor dalam implementasi Peraturan Daerah. Penarikan kesimpulan merupakan suatu kegiatan dari konfigurasi utuh selama penelitian berlangsung. Sedangkan verifikasi dilakukan selama peneliti menulis, dengan mengingat kembali catatan hasil lapang; atau verifikasi bisa secara menyeluruh dan mendetail, dengan argumen dan review yang panjang dengan para kolega untuk membuat "consensus inter-subyektif" atau dengan upaya yang ekstensif mengulangi temuan dalam serangkaian data lainnya. ${ }^{6}$

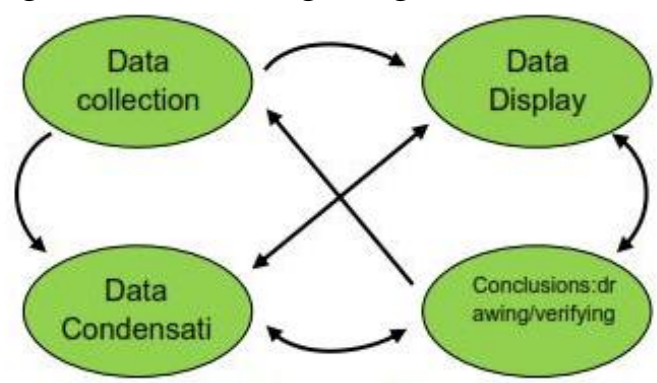

Gambar 1. Komponen-Komponen Analisis Data Model Interaktif

5 Djoko Heroe S. 2006. Eksistensi Hukum Ketenagakerjaan Dalam Menciptakan Hubungan Kemitraan Antara Pekerja Dengan Pengusaha, Disertasi, Pascasarjana, Fakultas Hukum Universitas Brawijaya.

${ }^{6}$ Dun Leavy, Patrick. 1988. Democracy, Bureaucracy and Public Choice. Cambrigde University Press, Cambrigde. 
292 \} A Azas-Azas Kebijakan Sistem Penyelenggaraan Ketenagakerjaan

\section{Indikator Capaian Terukur}

Keutamaan penelitian yang ingin dicapai dapat diukur dari keberhasilan mengidentifikasi Peran Aktor dalam Implementasi Peraturan Daerah Nomor 22 tahun 2012 tentang Sistem Ketenagakerjaan di Kabupaten Pasuruan. Selain itu indikator keberhasilan yang dapat diukur dari penelitian ini adalah mampu merekonstruksi model Implementasi Sistem Ketenagkerjaan di Kabupaten Pasuruan.

\section{Kerangka Operasional Penelitian}

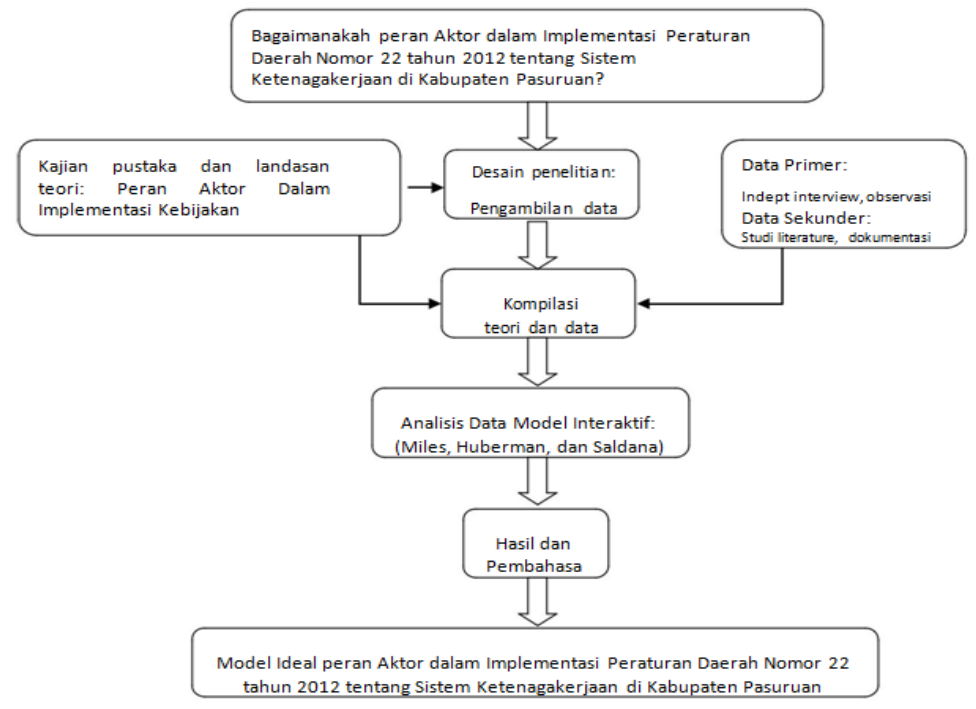

Gambar 2. Kerangka Operasional Penelitian

\section{HASIL DAN PEMBAHASAN}

Terdapat tiga aktor penting dalam implementasi Peraturan Daerah (Perda) Kabupaten Pasuruan Nomor 22 Tahun 2012 tentang Sistem Penyelenggaraan Ketenagakerjaan, antara lain: 1) Dinas Ketenagakerjaan dan Transmigrasi (Disnakertrans) Kabupaten Pasuruan (Pemerintah Daerah), 2) APINDO Kabupaten Pasuruan, dan 3) Serbumusi (Serikat Buruh Muslim Indonesia). Sebagaimana teori Grindle, ketiga aktor tersebut dipilih sebagai unsur (kelompok sasaran) yang paling berpengaruh dalam konten dan 
konteks implementasi Perda Nomor 22 Tahun 2012 tentang Sistem Penyelenggaraan Ketenagakerjaan di Kabupaten Pasuruan. ${ }^{7}$

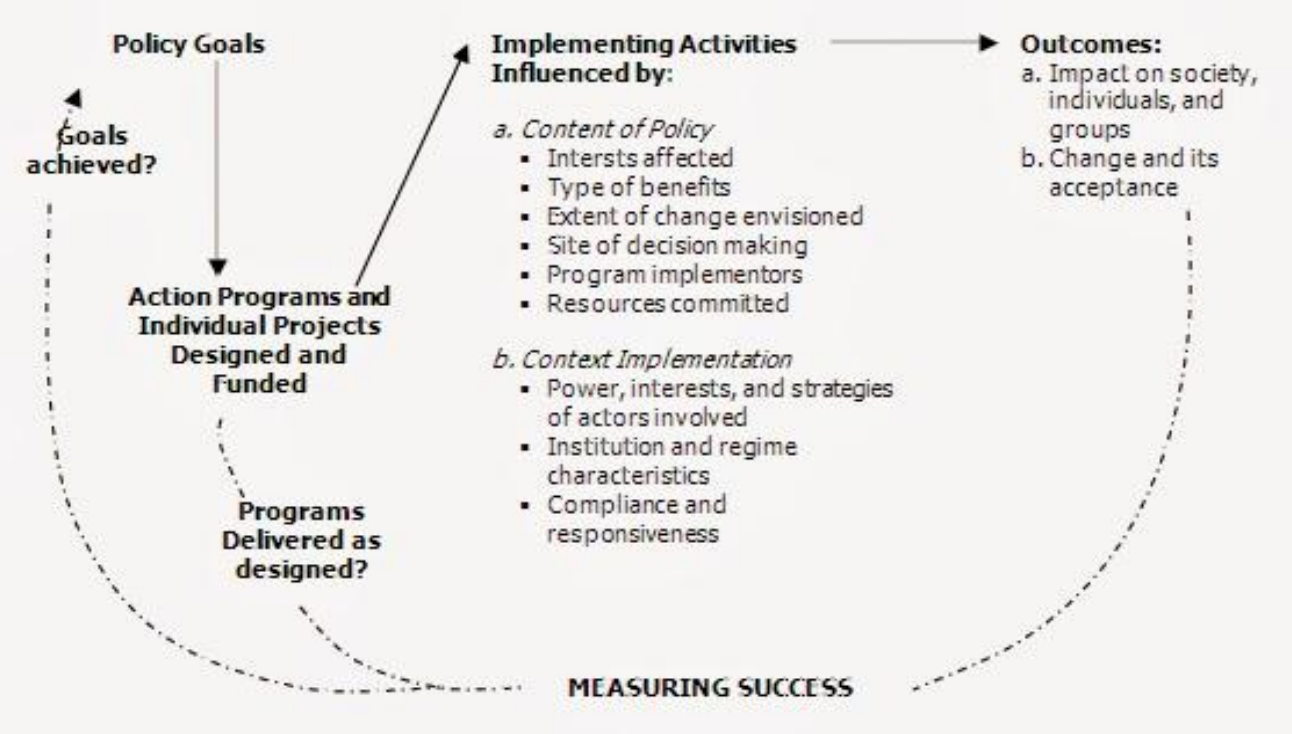

Gambar 3. Model Implementasi Kebijakan Grindle

Sumber: Merilee S. Grindle (2017:11)

\section{AZAS-AZAS IMPLEMENTASI DALAM KONTEN PERDA NO. 22 TAHUN 2012}

\section{Kepentingan kelompok sasaran}

Menurut Machmudi, ST. (wawancara, 2018), bidang Satker Disnakertrans Kbupaten Pasuruan bahwa dalam implementasi Perda nomor 22 tahun 2012 Disnaker berpendapat bahwa sampai saat ini stabil,dikarnakan sebagai keberlangsungan dunia usahan maupu pekerja, mampu memberikan lowongan lapangan kerja, infestasi perusahan lebih meningkat baik itu perusahan maupun tenaga kerja yang akhirnya mengurangi pengnganguran. Pada prinsipnya disnaker hanya sebatas sebagai mediasi kedua pihak antara apindo dan serikat. Jika kedua pihak ada kesepakatan dan saling menerima maka dengan otomatis disnaker tidak mempermasalahkan. ${ }^{8}$

\footnotetext{
7 Dun Leavy, Patrick. 1988. Democracy, Bureaucracy and Public Choice. Cambrigde University Press, Cambrigde.

${ }^{8}$ Sri Soemantri. 1977. Tentang Lembaga-Lembaga Negara Menurut UUD 1945, Alumni, Bandung.
} 
$294\}$ A Azas-Azas Kebijakan Sistem Penyelenggaraan Ketenagakerjaan

Sementara itu bagi APINDO Kabupaten Pasuruan, sebagaimana hasil wawancara dengan Hendro (ketua APINDO), ia mengatakan bahwa berbicara regulasi perda nomor 22 tahun 2012 secara substantif Perda tersebut sangat sarat dengan kepentingan politik, apalagi saat Pilkada sangat sarat adanya pengaruh terhadap serikat khususnya karyawan untuk simpatisan dan ajang janji serta adanya paham isu kenaikan gaji, walaupun prinsipnya upah mimimum kabupaten (UMK) yang mengeluarkan gubenur, kepala daerah juga ikut campur terkait dengan besaran kenaikan UMK. ${ }^{9}$

Secara historis, menurut Imam Hambali (wawancara, 2018), PAC SABUMUSI Purwosari bahwa awal mula munculnya Perda No. 22 tahun 2012 tersebut berasal dari usulan serikat pekerja yang direkomendasikan kepada Dewan Perwaklan Rakyat Daerah (DPRD) Kabupaten Pasuruan. Bagi Mahkamah Agung Peda tersebut tidak bertentangan dengan Undang-undang, sehingga Perda tersebut secara sah berlaku sampai sekarang. Dengan adanya perda tersebut, seluruh karyawan ada ketenagan tersendr dalam berkerja di sebuah perusahan yang ada di wilayah Kabupaten Pasuruan. Hal ni dkarenakan secara substansiil Perda tersebut sangat memihak kepada para pekerja yang dimotori oleh serikat pekerja. Misalnya saja salah satu isinya pada pasal 37 ayat 4 menyatakan bahwa "Pengusaha wajib menaikkan Upah Minimum bagi pekerja/buruh yang sudah menikah atau berkeluarga dan/atau sudah memiliki masa kerja 1 (satu) tahun atau lebih sekurang kurangnya 5 \% (lima persen) lebih besar dari Upah Minimum Kabupaten yang berlaku". ${ }^{10}$

\footnotetext{
${ }^{9}$ Simon, Herbert. A. 1988. Administrasi Behaviour. alih bahasa, St. Dianjuy, Bumi Aksara, Jakarta.

10 Djoko Heroe S. 2006. Eksistensi Hukum Ketenagakerjaan Dalam Menciptakan Hubungan Kemitraan Antara Pekerja Dengan Pengusaha, Disertasi, Pascasarjana, Fakultas Hukum Universitas Brawijaya.
}

..::: Malia: Jurnal Ekonomi Islam, Volume 10 Nomor 2 Juni 2019 :::... 


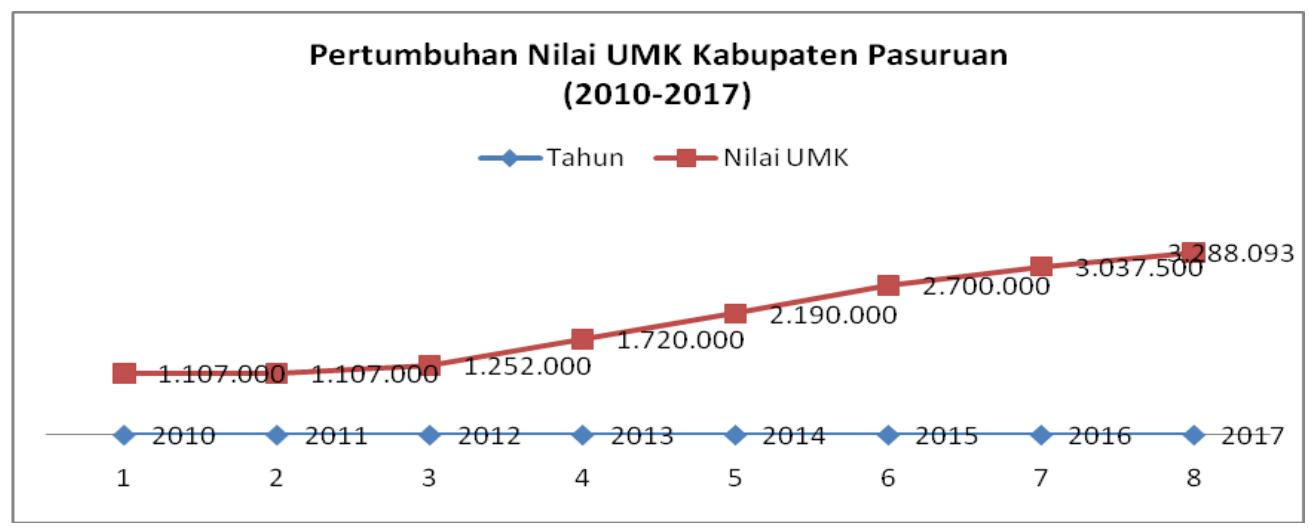

Gambar 4. Grafik Pertumbuhan Nilai UMK Kabupaten Pasuruan 2010-2017 Sumber: Dokumen PAC APINDO Purwosari Pasuruan

\section{Jenis Manfaat dari Perda No. 22 tahun 2012}

Secara konten menurut Machmudi Perda tersebut sangatlah baik itu merupakan sebagai pondasi dasar hukum baik untuk perusahan maupun bagi pekerja dan status perda sendiri masih berlaku belum di regulasi/perbaikan. Jika ada permasalahan maka disnaker melakukan perundingan dngan perusahan dengan pihak pekerja, dan jika belum ada solusi maka permasalahan di bawah ke HPI Pengadilan Hubungan Industri. Dalam penerapan perda no. 22 tahun 2012 tidak semua perusahan menerapkan kebijakan perda dengan alasan perusahan tidak mampu. Perda tersebut terdiri banyak pasal yang sulit diterapkan dan tidak ada pengawalan dalam implementasinnya. Jika dipaksakan perda yang ada maka banyak perusahan yang lari dari pasuruan dan berhenti. Pindah kedaerah lain contoh ke jember, Kediri, dan Jombang. Soal manfaat masih jauh, justru banyak masalah jika di tegakkan perda maka banyak yang tutup dan berakibat fatal untuk ekonomi pasuruan dan pengganguran makin banyak, yang akhirnya lebih banyak kenakalan yang mengarah perampasan sepeda motor bahkan lebih dari itu. Senada dengan pernyataan di atas, Hendro juga menyatakan bahwa manfaat perda ya bersifat ambigu regulasinya belum ada kepastian dalam implementasinya. ${ }^{11}$

11 Scheller, Randal. S dan Susan E. Jakcson. 1997. Human Resources Management, Positioning for the 21st Century. Sixth Ed., alih bahasa Nurdin Sobari dan Dwi Kartini Yahya, Gelora Aksara Pratama, Jakarta. 
296 \} A Azas-Azas Kebijakan Sistem Penyelenggaraan Ketenagakerjaan

Terbitnya Perda tersebut sangat bermanfaat bagi bagi serikat pekerja maupun buruh yang ada di lingkungan Kabupaten Pauruan. Memang disadari bahwa masih terdapat kelemahan-kelemahan dalam hal sosialisasi, pengawasan dan penindakan serta isi Perda secara keseluruhan belum dapat diimplementasikan sekaligus terdapat kesan terabaikan, Perda nomor 22 tahun 2012 tetap menjadi manufer dan keuntungan tersediri bagi serikat pekerja.

\section{Perubahan yang Diinginkan}

Bagi Mahmudi, soal perubahan yang diinginkan perda harus di tinjau ulang. Penerapan perusahan juga tidak banyak yang menjalankan perda itu sendiri, dan juga berjalannya perda tidak begitu jelas untuk itu perlu adanya perbaikan. Serta tidak banyak cukup adanya perubahan yang di terima oleh karyawan. Selain itu bagi Hendro, Soal perubahan dengan adanya perda itu, justru memperkeruh suasana. Mengapa demikian? karena Perda tersebut tidak di implementasikan dengan serius dari pihak baik apindo, serikat maupun dinas sendiri, buktinya diam-diam saja.

Sementara itu, bagi serikat pekerja (Imam Hambal), bahwa perubahan yang diinginkan belum dikaji kata ketua serikat Imam hambali, walaupun perda ini satu-satunya perda yang ada di Indonesia pasuruan. Dan isi sebagian isi perda masuk dlam perda pemprov Jawa Timur. Jangan bicara perubahan isi perda sendiri sebagian tidak di jalankan oleh karena itu bicara perubahan sangat jauh, akhirnya bicara perda atau menerapkan perda tidak ngefek untuk karyawan, jika dibahas hanya menghabiskan uang rakyat.

\section{Program}

Pada konten ini Mahmudi menyatakan bahwa Perda tersebut tidak bejalan justru banyak ketimpangan dengan peraturan diatasnya seperti undang-undang tahun 2013. Sistem outsourcing di perusahan banyak yang tidak sesuai dengan perda yang seharusnya diterapkan justru sebaliknya. Perda nomor 22 tahun 2012 awalnya rekomendasi dari serikat pekerja kepada Dewan Perwakilan Rakyat Daerah (DPRD), sehingga isi Perda banyak memihak kepada kepentingan pada serikat pekerja saja. Sedangkan menurut Hendro bahwa program-program perusahaan yang senafas dengan Perda tersebut saya menilai hingga saat ini tidak tepat, tidak ada peningkatan dari karyawan hanya sebatas perusahan tertentu 
yang mau menerapkan dan yang tidak menjalankan, dan juga tidak ada teguran. $^{12}$

Bagi serikat pekerja, Perda yang ada belum tepat sasaran, tergantung dari instansi yang terkait pemerintah kabupaten pasuruan. Walaupun Perda yang terkait dengan ketenagakerjaan itu juga belum efektif dan tidak maksimal yang mana dalam perda adanya pengawasan, penindakan, dan pembinaan itu pun juga tidak berjalan justru petugas dari dinas ketenagakerjaan pasuruan yang terkait di pindahkan ke propensi jawa timur, sehingga perda tersebut benar-benar tidak ada nilainya untuk serikat maupun apindo yang terjadi ada yang menjalankan ada juga yang tidak menjalankan dan akhir statusnya terabaikan serta ada sediki kecemburuan bagi perusahan yang mampu mnerapkan dengan perusahan yang tidak mampu.

Isi perda tidak terperinci dan tidak diimplementasikan secara utuh baik oleh serikat, maupun dari apindo dan pegawai disnaker sendiri hanya berdali kalau kedua pihak tidak ada keberatan saling menerima serta tidak ada pengaduan saya anggap tidak ada masalah, jika kami tegakkan yang bersangkutan juga tidak ada tuntutak maka yang ada berjalan apa adanya. Jika dari buruh ada tuntutan sebelum permasalahan tersebut selesai di tingkatan disnaker maupun pengadilan hungan industry kontrak karyawan suda habis, sehingga buruh mengambil titik aman diam dan menerima apa yang diputuskan oleh perusahan walaupun ini berat,dan disisi lain karyawan pertimbangan dengan sulitnya mencari pekerjaan dibandingkan harus melakukan tuntutan dan akhirnya kontrak kerja tidak di perpanjang justru mala di pecat seterusnnya. Kalau ini yang dihadapi maka satusatunya diam demi titik amannya serta untuk memenuhi kebtuhan keluarga. ${ }^{13}$

Perda sendiri pada statusnya pemerintah kurang sosilaisasi pada karyawan, walaupun iti perda suda ada, dan serikat pekerja juga kurang maksimalnya sosialissi pada karyawan buruh ini juga bagian dari kurangnya peran dari implemnetasi kebijakan perda sangat tidak efektif sekali, ada perda tapi tidak adanya nilai.

${ }^{12}$ Henry, Nicholas. 1988. Administrasi Negara dan Masalah-masalah Kenegaraan.

${ }^{13}$ Kencana Syafii Innu. 1999. Ilmu Administrasi Publik. Rineka Cipta, Jakarta.

..::: Malia: Jurnal Ekonomi Islam, Volume 10 Nomor 2 Juni 2019 :::.. 
$298\}$ A Azas-Azas Kebijakan Sistem Penyelenggaraan Ketenagakerjaan

\section{Dukungan Sumberdaya}

Untuk dukungan sumberdaya belum ada, karena dari berbagai actor tidak banyak melakukan perang dan engan menjalankan perda, disamping itu makna perda itu sendiri tidak jelas maka dukungan yang mana yang harus di jalankan. Menurut Mahmudi Perda tersebut tidak di jelaskan secara rinci, terkait hak dan keajiban apa yang harus di kerjakan oleh tiga aktor (tripartite). Walaupun UMK Kabupaten Pasuruan tinggi tidak banyak perusahan yang menjalankan atau menerapkan isi perda. Walaupun perda mengatakan babwah pengawasan, penindakan, pembinaan ada dalam aturan perda ada akantetapi sekarang sudah dialih fungsikan ke propensi jawa timur, sehingga makna perda adi bias. Nilai kesejahtraan tidak sebanding UMK yang tingi di pasuruan tidak banyak memberikan kontribusi pada warga masyarakat dalam peningkatan kesejahtraan warga di pasuruan. Kepentingan tidak seimbang atara serikat apindo, yg akhirnya perda terkesan tidak bermakna karena kedua pihak tidak saling mendukung melainkan berjalan sendiri-sendiri jadi isi perda pengawasan, penindakan, pembinaan tidak berlaku, serta tidak di permasalakan oleh tiga tripartite selama perusahan dengan karyawan ada kesepakatan saling menerima. Jadi menurut saya pribadi ": Machmudi “ perda yang ada perlu adanya perbaikan, soalnya kalau serikat menuntut UMK tinggi maka saya kuatir perusahan yang ada di pasuruan pindah mengingat tol sekarang bisa antar daerah. Bagi para pengusaha (APINDO) pun Perda tersebut bukan muatannya terinci akan tetapi tumpang tindi yang ada dengan peraturan dan undang-undang diatasnya.

Bagi serikat pekerja Perda yang ada kurang di dukung dengan sumberdaya yang memadai, kenapa perda tidak banyak dijalankan alasannya;Undang-undang suda berjalan, sehingga perda yang ada akahirnya tidak lagi jadi acuan sebagai bijakan, regulasi perda banyak ketimpangan dengan undang-undang serta terkesan perda diabaikan begitu saja. Maka dari itu pihak-pihak yang terkait seperti apindo, serikat dan disnaker sendiri terkesan tidak banyak menyikapi justru terkesan mengabaikan, jika pihak-pihak yang terkait tidak lagi peduli sehingga program-program yang ada hanya sebatas sebagai bahan pembicaraan yang tidak membawah makna nilai sebagaimana yang di amanatkan isi perda tersebut. 


\section{KESIMPULAN}

Sebagaimana hasil penelitian dan pembahasan di atas, maka dapat disimpulkan bahwa terdapat opini yang berbeda dari para aktor mengenai konten implementasi dalam konten Perda No. 22 tahun 2012 tentang sistem penyelenggaraan ketenagakerjaan Kabupaten Pasuruan: 1) Aktor pertama; bagi Disnakertrans Kabupaten Pasuruan bahwa dalam implementasi Perda nomor 22 tahun 2012 Disnaker berpendapat bahwa sampai saat ini stabil, dikarenakan sebagai keberlangsungan dunia usahan maupu pekerja, mampu memberikan lowongan lapangan kerja, infestasi perusahan lebih meningkat baik itu perusahan maupun tenaga kerja yang akhirnya mengurangi pengnganguran. Pada prinsipnya disnaker hanya sebatas sebagai mediasi kedua pihak antara apindo dan serikat. Jika kedua pihak ada kesepakatan dan saling menerima maka dengan otomatis disnaker tidak mempermasalahkan; 2) Aktor kedua; bagi APINDO Kabupaten Pasuruan, bahwa regulasi Perda nomor 22 tahun 2012 secara substantif Perda tersebut sangat sarat dengan kepentingan politik, apalagi saat Pilkada sangat sarat adanya pengaruh terhadap serikat khususnya karyawan untuk simpatisan dan ajang janji serta adanya paham isu kenaikan gaji, walaupun prinsipnya upah mimimum kabupaten (UMK) yang mengeluarkan gubenur, kepala daerah juga ikut campur terkait dengan besaran kenaikan UMK; Aktor tiga; bagi Serikar Pekerja (PAC SARBUMUSI Purwosari) bahwa awal mula munculnya Perda No. 22 tahun 2012 tersebut berasal dari usulan serikat pekerja yang direkomendasikan kepada Dewan Perwaklan Rakyat Daerah (DPRD) Kabupaten Pasuruan. Bagi Mahkamah Agung Peda tersebut tidak bertentangan dengan Undang-undang, sehingga Perda tersebut secara sah berlaku sampai sekarang. Dengan adanya perda tersebut, seluruh karyawan ada ketenagan tersendr dalam berkerja di sebuah perusahan yang ada di wilayah Kabupaten Pasuruan. Hal ni dkarenakan secara substansiil Perda tersebut sangat memihak kepada para pekerja yang dimotori oleh serikat pekerja. Misalnya saja salah satu isinya pada pasal 37 ayat 4 menyatakan bahwa "Pengusaha wajib menaikkan Upah Minimum bagi pekerja/buruh yang sudah menikah atau berkeluarga dan/atau sudah memiliki masa kerja 1 (satu) tahun atau lebih sekurang kurangnya 5 \% (lima persen) lebih besar dari Upah Minimum Kabupaten yang berlaku".

Dengan demikian Berdasarkan uraian tersebut dikemukakan beberapa saran/rekomendasi, antara lain: 1) Secara substansiil konten Perda No. 22 tahun 2012 tentang sistem penyelenggaraan ketenagakerjaan Kabupaten

..::: Malia: Jurnal Ekonomi Islam, Volume 10 Nomor 2 Juni 2019 :::.. 
$300\}$ \} Azas-Azas Kebijakan Sistem Penyelenggaraan Ketenagakerjaan

Pasuruan memiliki beberapa kelemahan sehingga perlu dilakukan peninjauan kembali khususnya dalam hal Pemerintah Daerah sebagai aktor pengawasan dan pengendalian kepatuhan aktor-aktor lainnya dalam impelentasi regulasi tersebut, dan 2) Peninjauan kembali atas Perda No. 22 tahun 2012 tentang sistem penyelenggaraan ketenagakerjaan Kabupaten Pasuruan perlu dipahami sebagai kepentingan bersama para aktor (Pemerintah Daerah, APINDO, da Serikat Pekerja) sehingga tidak berkesan menjadi media atau alat kepentingan politik sesaat saja.

\section{DAFTAR PUSTAKA}

Bellante, Don dan mark Jackson. 1983. Ekonomi Ketenagakerjaan. alih bahasa, Wimajaya, K. Liotohe, FEUI, Jakarta.

Cooper, J. Philip, Cs. 1998. Public Administration for the Twenty First Century.

Djoko Heroe S. 2006. Eksistensi Hukum Ketenagakerjaan Dalam Menciptakan Hubungan Kemitraan Antara Pekerja Dengan Pengusaha, Disertasi, Pascasarjana, Fakultas Hukum Universitas Brawijaya.

Dun Leavy, Patrick. 1988. Democracy, Bureaucracy and Public Choice. Cambrigde University Press, Cambrigde.

Frederickson, George, H. 1997. The Spirit of Public Administration. the Jossey Bass Inc. San Fransisco.

Grindle Merilee S. 2017. Politics and Policy Implementation in Third World. Princeton Legacy Library, United States of America

Hakim, Lukman. 1999. Kajian Kebijakan Publik. makalah pada diklat

SPAMEN angkatan V kelas E, Jakarta.

Harcourt Brace \& Co, Orlando.

Henry, Nicholas. 1988. Administrasi Negara dan Masalah-masalah Kenegaraan.

Ingleson Jonhn. 2015.Buru, Serikat, dan politik Indonesia pada 1920an1930an CV. Marjin Kiri Ragensi Melati Mas A9/Serpong, Tangerang Selatan 15323 www.marjinkiri.com.

Kencana Syafii Innu. 1999. Ilmu Administrasi Publik. Rineka Cipta, Jakarta. Koko Kosidin. 1996. Aspek-Aspek Hukum Dalam Pemutusan Hubungan Kerja Di Lingkungan Perusahaan Perseroan, Disertasi, Fakultas Hukum Univ. Pajajaran, Bandung. 
Mac.Millan. Alexander. 1983. Macro Economics. the Canadian Contect, Prentice Hall Inc., Canada.

Marzuki Peter Mahmud. 2005. Penelitian Hukum, Prenada Media, Jakarta.

Mathis, Robert. L dan John H. Jackon. 2001. Human Resources Management. Alih bahasa Jimmi Sadeli, Salemba Empat, Jakarta.

Mattew B. Miles, A. Michael Hubberman, and Johnny Saldana (2014). Qualitative Data Analysis: A Methods Sourcebook (3rd Edition) Arizona State University, CA: Sage Publications.

Mustopadidjaja, AR. 1999. Studi Kebijakan, Perkembangan dan Penerapannya dalam rangka Administrasi dan Manajemen Pembangunan. FEUI, Jakarta.

New York.

Rahardjo S. 2000. Ilmu Hukum, Citra Aditya Bakti, Yogyakarta.

Red Ford, Emmette. 1975. Ideal and Practice In Public Administration. University Alabama.

Rosen Bloom, David. H. 1986. Public and Administration. Random House, Inc.

Scheller, Randal. S dan Susan E. Jakcson. 1997. Human Resources Management, Positioning for the 21st Century. Sixth Ed., alih bahasa Nurdin Sobari dan Dwi Kartini Yahya, Gelora Aksara Pratama, Jakarta.

Simon, Herbert. A. 1988. Administrasi Behaviour. alih bahasa, St. Dianjuy, Bumi Aksara, Jakarta.

Sri Soemantri. 1977. Tentang Lembaga-Lembaga Negara Menurut UUD 1945, Alumni, Bandung.

Susanto Harris. 2012 Matinya Sang Buruh Penerbit Koekoesan Jl.KH.Ahmad Dahlan V.N0.10 Kukusan, Depok.

Yasin, Moch. 2000. Dasar-dasar Demografi. Lembaga Demografi FEUI, Jakarta. 
302 \} Azas-Azas Kebijakan Sistem Penyelenggaraan Ketenagakerjaan

..::: Malia: Jurnal Ekonomi Islam, Volume 10 Nomor 2 Juni 2019 :::... 